\title{
SPECTROPHOTOMETRIC DETERMINATION OF AMITRIPTYLINE HCI IN PURE AND PHARMACEUTICAL FORMS
}

\author{
K. SUSMITHA ${ }^{1}$, M.THIRUMALACHAR $Y^{1}$,T.CHARAN SINGH ${ }^{2}$ AND G VENKATESHWARLU*
}

\author{
${ }^{1}$ Department of Chemistry, Jawaharlal Nehru Technology University Kukatpally, Hyderabad-500 085 , \\ ${ }^{2}$ Department of Chemistry, G.Narayanamma Institute of Science \& Technology \\ "Department of Chemistry, Nizam College, Hyderabad 500001, A.P. India \\ (Received: December 18, 2012 - Accepted: January 15, 2013)
}

\begin{abstract}
Five spectrophotometric methods for determination of Amitriptyline $\mathrm{HCl}$ have been developed, validated and applied for the assay of the drug in pharmaceuticals. Methods A, B and C are based on ion pair complexation of drug, in acidic buffers, with triphenylmethane dyes viz., Bromothymol blue (BTB), Bromophenol blue (BPB) and Bromocresol purple (BCP). The complexes are extracted into chloroform and absorbance is measured around at $415 \mathrm{~nm}$ as function of concentration of the drug. The stoichiometry of the complex is found 1:1 in each case. Method D depends upon charge transfer complexation of neutralized drug with iodine which produces iodide ion whose absorbance at $366 \mathrm{~nm}$ is measured as function of concentration of the drug. This complex, too, has 1:1 composition as determined by Job's method. Method $\mathrm{E}$ is developed on the basis of oxidation of the drug with alkaline $\mathrm{KMnO}_{4}$ which generates green colored manganate ion with $\lambda \max 610 \mathrm{~nm}$. As the intensity of green color increased with increasing time kinetics of the reaction is followed and calibration curves are constructed by using initial rate and fixed time methods. Excellent recovery studies with high accuracy and precision indicate that the methods can be successfully used in industries for the assay of drug in pure form and pharmaceuticals.
\end{abstract}

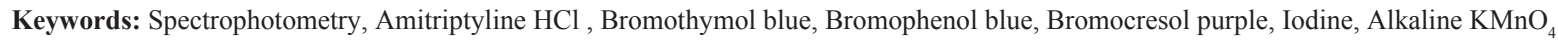

\section{INTRODUCTION}

Amitriptyline $\mathrm{HCl}$ (AMT) chemically [3-(10, 11-dihydro-5H-dibenzol [a, d] cyclohept-5-ylidene) propyldimethylamine] hydrochloride constitute an important class of neurotherapeutics ${ }^{1}$ belonging to first generation of antidepressant drug ${ }^{2,3}$ It may be used to treat depression, irritable bowel syndrome, diabetic neuropathy, post-traumatic stress disorder and for migraine prophylaxis. Various analytical methods developed for determination of amitriptyline $\mathrm{HCl}$ viz., spectrophotometric ${ }^{4-11}$, spectrofluorometric ${ }^{12}$, flow injection method ${ }^{13}$, atomic absorption spectroscopic ${ }^{14}$, conductometric ${ }^{15,16}$, voltammetric ${ }^{17}$, UPLC-MS/MS ${ }^{18}$ MEPS by LC\&GC-MS ${ }^{19}$, Electrogenerated Chemiluminescence ${ }^{20}$ and HPLC ${ }^{21}$ methods have been enumerated.

Table I. Comparison with other quantification methods for the determination of Amitriptyline hydrochloride

\begin{tabular}{|c|l|c|c|c|}
\hline S.No. & \multicolumn{1}{|c|}{ Method } & $\lambda \max (\mathrm{nm})$ & Working range & Remarks \\
\hline 1 & Spectrophotometric $\left\{\right.$ AMIYTP( $\left.(\beta \mathrm{CD})(\mathrm{PEG})_{3}\right\}$ & 242 & $0.1-1.0 \mu \mathrm{gmL}^{-1}$ & costly reagents \\
\hline 2 & CT Complexation with TCNQ & 842 & $10-300 \mu \mathrm{gmL}^{-1}$ & low sensitivity \\
\hline 3 & Extractive spectrophotometry & & $1-30 \mu \mathrm{gmL}^{-1}$ & \\
\hline & molybdedum and thiocyanate & & $0.08-0.360 \mu \mathrm{gmL}^{-1}$ & \\
\hline 4 & MEPS by LC \& GC-MS & & $0.09-0.24 \mu \mathrm{gmL}^{-1}$ & Involves $^{-1}$ \\
\hline 5 & Electrogenerated Chemiluminescence & & $0.05-1.3 \mu \mathrm{gmL}^{-1}$ & Expensive $^{\text {instruments }}$ \\
\hline 6 & Spectrofluorimetry & & $2.47-7.5 \mu \mathrm{gmL}^{-1}$ & \\
\hline 7 & HPTLC & & $0.01-0.035 \mu \mathrm{gmL}^{-1}$ & \\
\hline 8 & RP-HPTLC & & & \\
\hline
\end{tabular}

From the comparison table it is clear that the methods used so far for quantification of AMT suffer from involving costly equipment ${ }^{7,12,19,20}$ or costly chemicals 4,6 or instruments with low sensitivity ${ }^{8}$ and not useful for routine laboratory analysis. Therefore it seems necessary to develop a sensitive, simple and rapid determination of Amitriptyline $\mathrm{HCl}$. In the present communication we report five quantification methods viz., A, B, C, D, and E which have been developed and validated for quantification of Amitriptyline $\mathrm{HCl}$ both in pure and pharmaceutical forms.

\section{EXPERIMENTAL}

\subsection{Instruments}

The UV--Visible spectra of the samples were recorded on SHIMADZU 140 double beam, Thermo Nicolet 1000 and ELICO 159 UV-Visible single beam spectrophotometers using quartz cells of $10 \mathrm{~mm}$ path length. An Elico model Li-120 $p \mathrm{H}$ meter was used for $p \mathrm{H}$ measurement.

2.2 Materials

HPLC grade chloroform, 1, 2 Dichloroethane (DCE), Analytical grade (AR) $\mathrm{HCl}$, Sodium acetate, $\mathrm{KMnO}_{4}$, Sodium hydroxide and dyes viz., a) BTB b) BPB c) BCP supplied by Sd Fine Chemicals, Mumbai were used in the study. Iodine (BDH, Poole, UK) was twice sublimed and preserved in vacuum desiccator (mp $113.6-3^{\circ} \mathrm{C}$ ). Iodine in 1,2 dichloroethane was freshly prepared (daily) by dissolving $254 \mathrm{mg}$ solute in $50 \mathrm{~mL}$ of solvent $\left(4.0 \times 10^{-3} \mathrm{M}\right)$. The drug was procured from Aurobindo Pharmaceiticals, Hyderabad, as gift sample.

Neutralisation is carried out by dissolving $100 \mathrm{mg}$ of AMT in $10 \mathrm{~mL}$ of distilled water and solution is transferred into $100 \mathrm{~mL}$ separating funnel and rendered alkaline with $5 \mathrm{~mL}$ of $0.45 \mathrm{M} \mathrm{NaOH}$ solution.The liberated base is extracted with three times, each with $25 \mathrm{~mL}$ of 1,2 Dichloroethane.The solution is further diluted with same solvent to obtain the working solution.

2.3. Methods A, B and C

The methods $\mathrm{A}, \mathrm{B}$ and $\mathrm{C}$ are based on the interaction of the drug with Bromothymol blue (BTB), Bromophenol blue (BPB) and Bromocresol purple 
(BCP) respectively, to form chloroform extractable ion pair complexes (Scheme 1) which absorb around $415 \mathrm{~nm}$. (Fig. 1) The absorbance of this band increases with increasing the concentration of the drug and formed a basis for the quantification of the drug. The dyestuffs were used as $0.025 \%$ solutions in doubly distilled water. Sodium acetate-hydrochloric acid buffers of $p \mathrm{H} 2.8,2.5$ and 2.5 were prepared by mixing $50 \mathrm{ml}$ of $1.0 \mathrm{M}$ sodium acetate solution with $49.50 \mathrm{~mL}, 50.50 \mathrm{~mL}$ and $50.50 \mathrm{~mL}$ of $1.0 \mathrm{M} \mathrm{HCl}$ solution respectively and diluted to $250 \mathrm{~mL}$ with doubly distilled water. The $p \mathrm{H}$ of each solution was adjusted to an appropriate value with the aid of a $p \mathrm{H}$ meter.

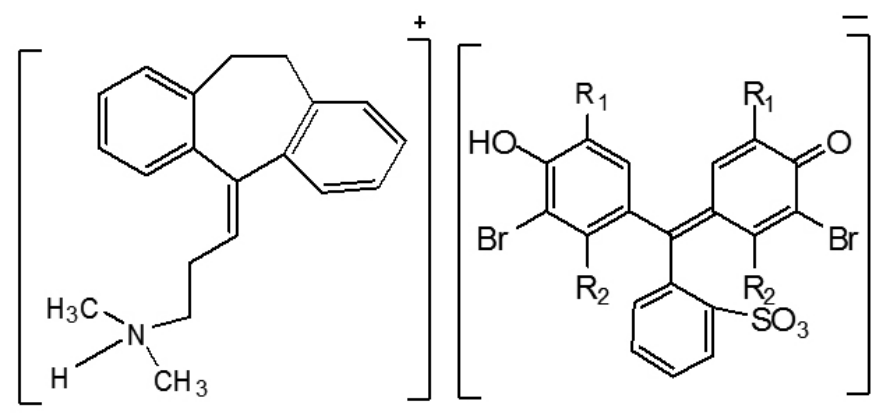

Bromothymol blue: $\mathrm{R}_{1}=$ isopropyl, $\mathrm{R}_{2}=\mathrm{CH}_{3}$ Bromophenol blue: $\mathrm{R}_{1}=\mathrm{Br}, \mathrm{R}_{2}=\mathrm{H}$ Bromocresolpurple: $\mathrm{R}_{1}=. \mathrm{CH}_{3}, \mathrm{R}_{2}=\mathrm{H}$

Scheme 1 Amitriptyline $\mathrm{HCl}$ - dye complex

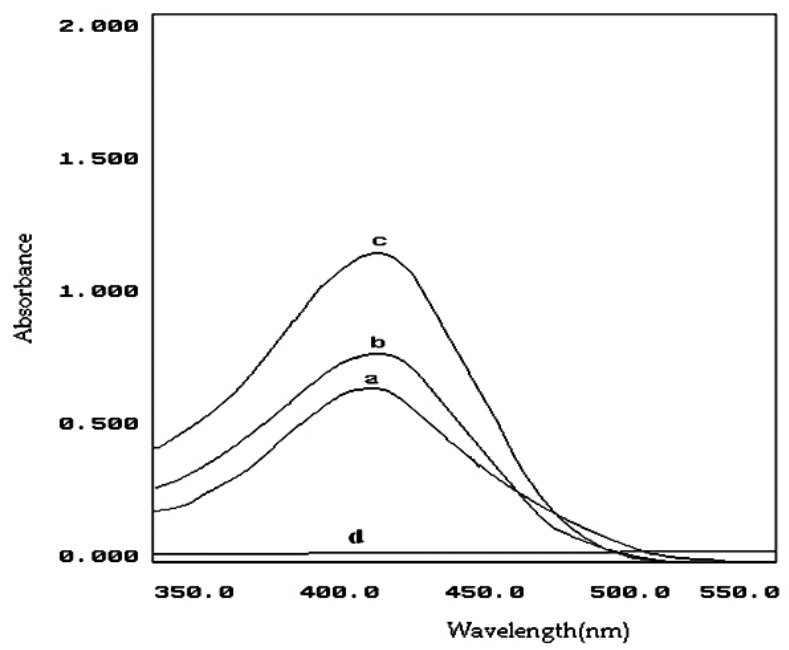

Figure1. Absorption spectra of Amitriptyline Hydrochloride - dyes complex extracted into $10 \mathrm{~mL}$ chloroform:

(a) drug $=20 \mu \mathrm{g} \mathrm{mL}-1+5 \mathrm{~mL}$ of $0.025 \% \mathrm{BTB}+5 \mathrm{~mL}$ of $p \mathrm{H} 2.8$ buffer;

(b) drug $=20 \mu \mathrm{g} \mathrm{mL}^{-1}+5 \mathrm{~mL}$ of $0.025 \% \mathrm{BPB}+5 \mathrm{~mL}$ of $p \mathrm{H} 2.5$ buffer;

(c) drug $=22.5 \mu \mathrm{g} \mathrm{mL}-1+5 \mathrm{~mL}$ of $0.025 \% \mathrm{BCP}+5 \mathrm{~mL}$ of $p \mathrm{H} 2.5$ buffer,

(d) drug $=0 \mu \mathrm{g} \mathrm{mL}-1+5 \mathrm{~mL}$ of $0.025 \% \mathrm{Dye}+5 \mathrm{~mL}$ of buffer

\subsection{Method D}

The method depends upon the interaction of neutralized drug with Iodine that generates iodide ion having an absorption band at $366 \mathrm{~nm}$. (Fig. 2) The absorbance of this band increases with increasing the concentration of the drug and formed a basis for the quantification of the drug. Mixing the solution of iodine prepared in DCE with AMT resulted in a change of violet color of iodine into light brown to pale yellow and as a consequence, absorption spectra exhibited a new band of $366 \mathrm{~nm}$. This is attributed due to $\mathrm{I}_{3}-$ ion formed by the interaction of iodine with drug. (Scheme 2).

$\mathrm{D}+\mathrm{I}_{2} \rightleftharpoons \mathrm{DI}_{2}$ (Outer complex) fast............1

DI $($ Outer complex $) \rightleftharpoons\left(\mathrm{DI}^{+}\right) \mathrm{I}^{-}($inner complex $)$slow.........2

$\left(\mathrm{DI}^{+}\right) \mathrm{I}^{-}($inner complex $)+\mathrm{I}_{2} \rightleftharpoons\left(\mathrm{DI}^{+}\right)+\mathrm{I}_{3}^{-}$fast...........

Scheme -2

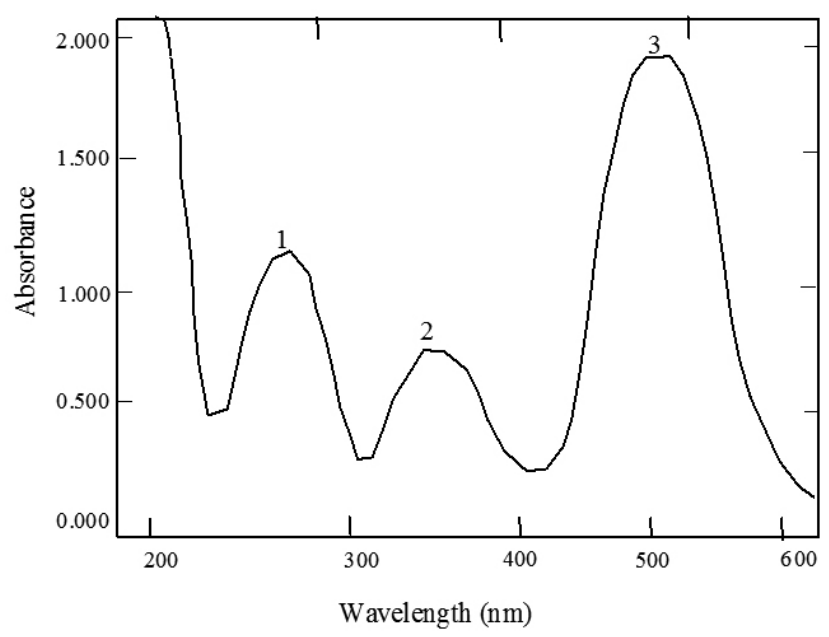

Figure 2. Absorption spectra (2) reaction product of $5 \mu \mathrm{g} \mathrm{mL}$ ${ }^{1}$ Amitriptyline hydrochloride with iodine in 1,2 Dichloroethane (3) iodine

\subsection{Method E Kinetic method}

The method depends on the oxidation of the drug with alkaline $\mathrm{KMnO}_{4}$ $\left(1 \times 10^{-2} M\right)$ to produce Manganate ion which absorbs at $610 \mathrm{~nm}$ (Fig.3) and formed a basis for quantification of drug. A solution of $0.45 \mathrm{M} \mathrm{NaOH}$ is used to produce required alkalinity. Mixing the solutions of permanganate and the drug slowly developed green color and hence kinetics of the reaction was followed spectrophotometrically. The initial rate and fixed time methods are followed for the determination of AMT. The literature survey reveals that Amitriptyline undergoes oxidation at exocyclic double bond and gives rise to dibenzosuberone ${ }^{22}$. (Scheme -3 )

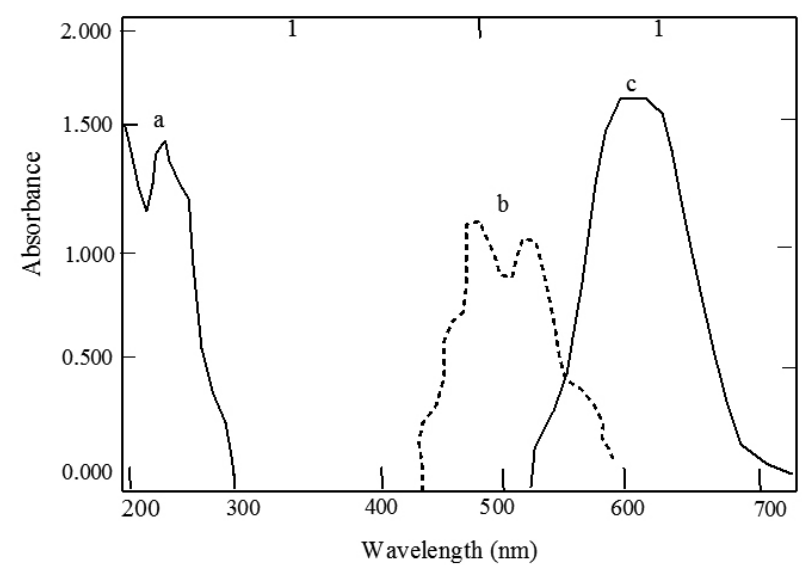

Figure 3. Absorption spectra of (a) Drug (b) $\mathrm{KMnO}_{4}\left(1 \times 10^{-2} \mathrm{M}\right)$ (c) Reaction product of $10 \mu \mathrm{g} \mathrm{mL}^{-1}$ Amitriptyline hydrochloride with alkaline $\mathrm{KMnO}_{4}$
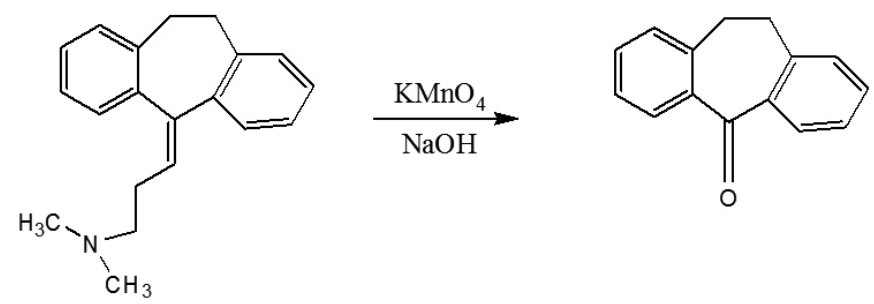

Scheme - 3 Oxidation of Amitriptyline $\mathrm{HCl}$ with alkaline $\mathrm{KMnO}_{4}$

2.6. Calibration curves for method $A, B$ and $C$

Different aliquots of drug solution were transferred into $125 \mathrm{~mL}$ separating 
funnel. To this $5 \mathrm{~mL}$ of buffer, $5 \mathrm{~mL}$ of dye were added and total volume was made up to $20 \mathrm{~mL}$ with water. $10 \mathrm{~mL}$ of chloroform was added and the contents were shaken for $5 \mathrm{~min}$. The two layers were allowed to separate for $5 \mathrm{~min}$ and the organic layer was separated and absorbance of yellow colored solution which is stable at least for $3 \mathrm{hr}$ is measured at $415 \mathrm{~nm}$ against blank similarly prepared. The same procedure of analysis is followed either for assay of pure drug or for dosage form. The calibration graphs are linear over a range of drug $1.25-25 \mu \mathrm{gmL}^{-1}$ (BTB), $1.5-25 \mu \mathrm{gmL}^{-1}$ (BPB), $2.0-25 \mu \mathrm{gmL}^{-1}$ (BCP).

\subsection{Calibration curve for method $D$}

Into separate $10 \mathrm{~mL}$ of volumetric flasks different aliquots of AMT solution was transferred followed by the addition of $1 \mathrm{~mL}$ of iodine solution. The volume was completed using the 1,2 dichloroethane solvent and the absorbance was measured against reagent blank at $366 \mathrm{~nm}$ and calibration curve is linear over a range of drug $2.5-25 \mu \mathrm{gmL}^{-1}$

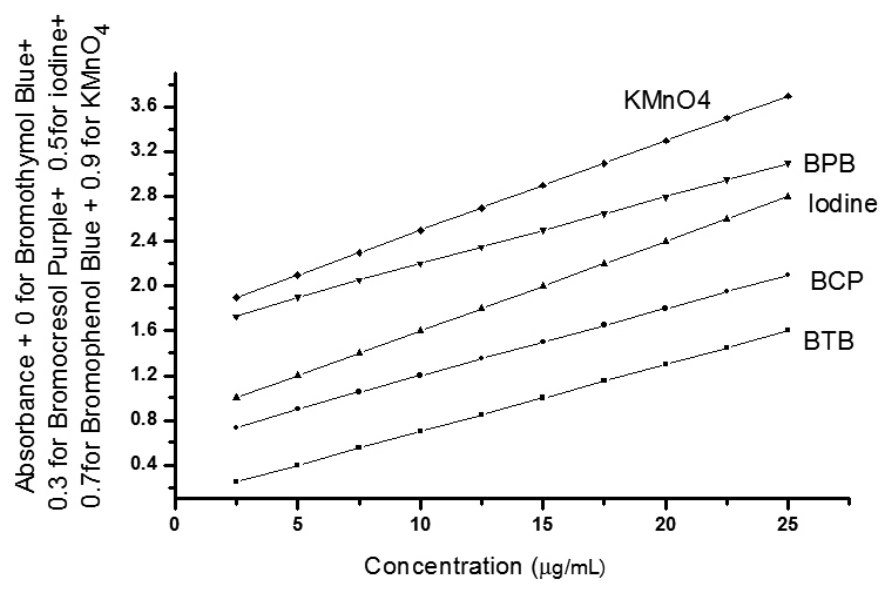

Figure 4. Calibration curves
2.8. Calibration curve for method $E$

The calibration curves are constructed by using initial rate method and fixed time method.

\subsubsection{Initial rate method}

Aliquots of 1 to $8 \mathrm{~mL}$ of Amitriptyline $\mathrm{HCl}$ solution containing $2.5 \mathrm{mg}$ $\mathrm{mL}^{-1}$ of drug were pipetted into a series of $10 \mathrm{~mL}$ standard flasks. To each flask, $1.0 \mathrm{~mL}$ of $0.45 \mathrm{M} \mathrm{NaOH}$ and $1 \mathrm{~mL}$ of $1 \times 10^{-2} \mathrm{M}$ potassium permanganate were added successively and then diluted with distilled water at $25 \pm 1^{\circ} \mathrm{C}$. The contents of each flask were mixed well, and the increase in absorbance as a function of time was measured at $610 \mathrm{~nm}$. The initial rate of the reaction at different concentrations was evaluated by deferring the slope of the tangent to the absorbance-time plot. The calibration graphs in the range 6.25 $50 \mu \mathrm{gmL}^{1}$ were obtained by plotting the initial rate of reaction versus the molar concentration of the Amitriptyline $\mathrm{HCl}$ (Fig . 4)

\subsubsection{Fixed time method}

A fixed time of $25 \mathrm{~min}$ was selected for the fixed time method. At this time the absorbance of reaction mixture was measured at $610 \mathrm{~nm}$ against a reagent blank prepared similarly. The calibration curve was obtained by plotting the absorbance against concentration of Amitriptyline $\mathrm{HCl}$.

\subsection{Assay of drug in pharmaceuticals}

\subsubsection{Procedure for the assay of pure drug}

Five different solutions of pure drug in the range of calibration curve were selected and the recovery experiments were performed. The recoveries and their relative standard deviation are tabulated in Table III.

2.9.2. Procedure for the assay of dosage forms

Five tablets of Elavil $10 \mathrm{mg}$ with composition Amitriptyline $\mathrm{HCl}-10$ mg, microcrystalline cellulose, croscarmellose sodium, magnesium stearate, colloidal silicon dioxide, hydroxyl propyl methyl cellulose, polyethylene glycol, carnauba wax are powdered and dissolved in doubly distilled water and stirred thoroughly, filtered through a Whatman No. 42 filter paper. This solution was transferred into $100 \mathrm{~mL}$ standard volumetric flask and diluted with doubly distilled water as required. Different solutions of drug in the range of calibration curve were chosen and its quantify was estimated using the calibration curve and the results of the recovery studies are tabulated in Table IV.

Table II Performance data for the proposed methods.

\begin{tabular}{|c|c|c|c|c|c|}
\hline Parameters & $\mathbf{A}$ & B & $\mathbf{C}$ & D & $\mathbf{E}$ \\
\hline$\lambda_{\max }(\mathrm{nm})$ & 415 & 410 & 415 & 366 & 610 \\
\hline Beer's law limit $\left(\mu \mathrm{g} \mathrm{mL}^{-1}\right)$ & $1.25-25$ & $1.5-25$ & $2.0-25$ & $2.5-25$ & $6.25-50$ \\
\hline Sandell sensitivity $\left(\mu \mathrm{g} \mathrm{cm}^{-2}\right)$ & 0.0169 & 0.0131 & 0.0147 & 0.014 & 0.0823 \\
\hline Slope, a & 0.059 & 0.0766 & 0.0680 & 0.071 & 0.0121 \\
\hline Intercept $b$ & 0.1164 & 0.1140 & -0.0710 & 0.0107 & 0.0192 \\
\hline Correlation coefficient $(\mathrm{r})$ & 0.9997 & 0.9988 & 0.9944 & 0.9987 & 0.9967 \\
\hline Standard deviation of intercepts $(\% \mathrm{n}=6)$ & 0.0150 & 0.0320 & 0.0200 & 0.021 & 0.02 \\
\hline Limit of detection, $\left(\mu \mathrm{gmL}^{-1)}\right.$ & 0.80 & 1.30 & 0.97 & 0.9 & 5.4 \\
\hline Limit of quantification, $\left(\mu \mathrm{gmL}^{-1)}\right.$ & 2.40 & 3.90 & 2.91 & 2.9 & 16.2 \\
\hline Regression equation $\mathrm{Y}=\mathrm{a}{ }^{*} \mathrm{C}+\mathrm{b}$ & $\begin{array}{c}\mathrm{Y}= \\
0.059 * \mathrm{C}+0.1164\end{array}$ & $\begin{array}{c}\mathrm{Y}= \\
0.0766^{*} \mathrm{C}+0.114\end{array}$ & $\begin{array}{c}\mathrm{Y}= \\
0.068^{*} \mathrm{C}-0.071\end{array}$ & $\begin{array}{c}\mathrm{Y}= \\
0.071 * \mathrm{C}+0.010\end{array}$ & $\begin{array}{c}\mathrm{Y}= \\
0.0121 * \mathrm{C}+0.019\end{array}$ \\
\hline
\end{tabular}

$\mathrm{Y}=\mathrm{a} * \mathrm{C}+\mathrm{b}$, Where $\mathrm{C}$ is the concentration in $\mu \mathrm{gmL}^{-1}$ 
J. Chil. Chem. Soc., 59, No 1 (2014)

Table III. Application of proposed methods for the determination of AMT in pure form.

\begin{tabular}{|c|c|c|c|c|c|}
\hline & $\mathbf{A}$ & B & $\mathbf{C}$ & D & $\mathbf{E}$ \\
\hline \multirow[t]{5}{*}{ Amount taken $\left(\mu \mathrm{g} \mathrm{mL}^{-1}\right)$} & 10.00 & 10.00 & 10.00 & 10.00 & 10.00 \\
\hline & 15.00 & 15.00 & 15.00 & 15.00 & 15.00 \\
\hline & 20.00 & 20.00 & 20.00 & 20.00 & 20.00 \\
\hline & 25.00 & 25.00 & 25.00 & 25.00 & 25.00 \\
\hline & 30.00 & 30.00 & 30.00 & 30.00 & 30.00 \\
\hline \multirow[t]{5}{*}{$\begin{array}{l}\text { Amount found } \\
\left(\mu \mathrm{g} \mathrm{mL} L^{-1}\right)\end{array}$} & 9.98 & 10.22 & 10.15 & 9.98 & 9.99 \\
\hline & 15.04 & 14.96 & 15.07 & 14.96 & 15.01 \\
\hline & 20.06 & 19.99 & 20.09 & 19.97 & 19.99 \\
\hline & 25.28 & 25.05 & 25.10 & 24.19 & 25.05 \\
\hline & 29.99 & 30.05 & 30.05 & 29.87 & 30.08 \\
\hline \multirow[t]{5}{*}{ Recovery (\%) } & 99.8 & 102.2 & 101.5 & 99.32 & 99.9 \\
\hline & 100.27 & 99.73 & 100.47 & 100.74 & 100 \\
\hline & 100.3 & 99.95 & 100.45 & 100.50 & 99.95 \\
\hline & 101.12 & 100.2 & 100.4 & 100.20 & 100.2 \\
\hline & 99.97 & 100.17 & 100.17 & 99.56 & 100.2 \\
\hline Mean \pm SD & $100.29 \pm 0.50$ & $100.45 \pm 0.99$ & $100.60 \pm 0.51$ & $100.06 \pm 0.608$ & $100.05 \pm 0.141$ \\
\hline \multirow[t]{2}{*}{ Reference method ${ }^{4}$ Mean \pm SD } & $100.33 \pm$ & $100.33 \pm$ & $100.33 \pm$ & $100.33 \pm$ & $100.33 \pm$ \\
\hline & 0.44 & 0.44 & 0.44 & 0.44 & 0.44 \\
\hline t-test*(2.306) & 0.134 & 0.247 & 0.896 & 0.804 & 1.35 \\
\hline F-test*(5.05) & 1.29 & 5 & 1.3 & 1.9 & 0.9 \\
\hline
\end{tabular}

Each result is the average of five separate determinations. *Values in parenthesis are the tabulated $\mathrm{t}$ and $\mathrm{F}$ values at $\mathrm{p}=0.05^{23}$

Table IV. Application of proposed methods for the determination of AMT in Pharmaceutical form.

\begin{tabular}{|c|c|c|c|c|c|}
\hline & $\mathbf{A}$ & B & $\mathbf{C}$ & D & $\mathbf{E}$ \\
\hline \multirow[t]{5}{*}{ Amount taken $\left(\mu \mathrm{g} \mathrm{mL} L^{-1}\right)($ Elavil $-10 \mathrm{mg})$} & 10.00 & 10.00 & 10.00 & 10.00 & 10.00 \\
\hline & 20.00 & 20.00 & 20.00 & 20.00 & 20.00 \\
\hline & 30.00 & 30.00 & 30.00 & 30.00 & 30.00 \\
\hline & 40.00 & 40.00 & 40.00 & 40.00 & 40.00 \\
\hline & 50.00 & 50.00 & 50.00 & 50.00 & 50.00 \\
\hline \multirow[t]{5}{*}{ Amount found $\quad\left(\mu \mathrm{g} \mathrm{mL}^{-1}\right)$} & 9.98 & 10.02 & 9.95 & 9.98 & 9.97 \\
\hline & 20.02 & 19.95 & 20.15 & 20.03 & 19.98 \\
\hline & 29.96 & 30.10 & 30.15 & 29.95 & 29.88 \\
\hline & 39.00 & 40.05 & 39.77 & 39.55 & 39.88 \\
\hline & 49.60 & 50.11 & 50.22 & 49.4 & 50.8 \\
\hline \multirow[t]{5}{*}{ Recovery (\%) } & 99.8 & 100.2 & 99.5 & 99.80 & 99.7 \\
\hline & 100.1 & 99.75 & 100.75 & 100.15 & 99.9 \\
\hline & 99.87 & 100.33 & 100.5 & 99.83 & 99.6 \\
\hline & 97.5 & 100.13 & 99.43 & 98.88 & 99.7 \\
\hline & 99.2 & 100.22 & 100.44 & 98.80 & 101.6 \\
\hline Mean \pm SD & $99.29 \pm 1.06$ & $100.13 \pm 0.22$ & $100.12 \pm 0.61$ & $99.49 \pm 0.613$ & $100.1 \pm 0.845$ \\
\hline \multirow[t]{2}{*}{ Reference method ${ }^{4}$ Mean \pm SD } & $100.33 \pm$ & $100.33 \pm$ & $100.33 \pm$ & $100.33 \pm$ & $100.33 \pm$ \\
\hline & 0.44 & 0.44 & 0.44 & 0.44 & 0.44 \\
\hline t-test*(2.306) & 1.617 & 0.045 & 0.01 & 2.28 & 0.539 \\
\hline F-test*(5.05) & 5.8 & 0.2 & 1.9 & 1.9 & 3.6 \\
\hline
\end{tabular}

*Values in parenthesis are the tabulated $\mathrm{t}$ and $\mathrm{F}$ values at $\mathrm{p}=0.05^{23}$ 


\section{RESULTS AND DISCUSSION}

\subsection{Methods A, B and C}

AMT forms ion-pair complexes in acidic buffer with dyestuffs viz., BTB, $\mathrm{BPB}$ and BCP which are quantitatively extracted into chloroform. Ion-pair complexes of drug with dyes absorbed maximally at $415 \mathrm{~nm}$ (Fig. 1). AMT contains a tertiary nitrogen atom and in strongly acidic medium it exists as a cation and sulphonic acid group present in the dyes that is the only group undergoing dissociation in the $p \mathrm{H}$ range 1-5. Finally the protonated AMT forms ion-pairs with the dyestuff which is quantitatively extracted into chloroform.

\subsection{Stoichiometry}

In order to establish molar ratio between AMT and dyestuffs used, the Job's method of continuous variation has been applied ${ }^{24}$. In this method, solutions of drug and dyestuff with identical molar concentrations $\left[8 \times 10^{-5} \mathrm{M}\right]$ were mixed in varying volume ratios in such a way that the total volume of each mixture is the same. The absorbance of each solution was measured and plotted against the mole fraction of the drug, $[\mathrm{drug}] /[\mathrm{drug}]+[$ dyestuff $]$. This measurement showed that 1:1 complex was formed.

The Job's method of stoichiometry is also applied for Iodine with AMT which indicated the charge transfer complex formed is of 1:1 composition (Fig $5)$.

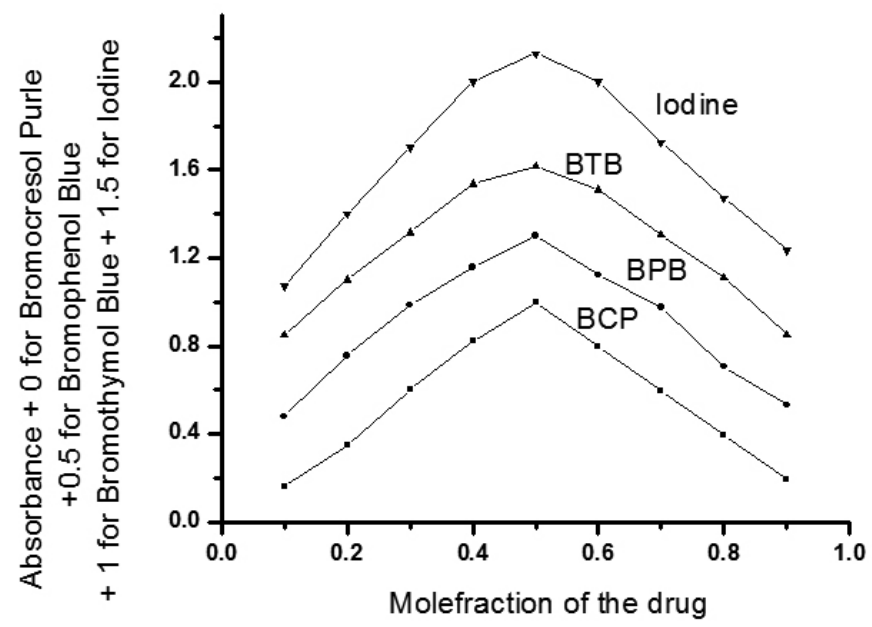

Figure 5. Jobs continuous variation plot-

The stoichiometric ratio between Amitriptyline and potassium permanganate was evaluated by limiting logarithmic method ${ }^{25}$. The method involves two sets of experiments. In the first set the concentration of AMT was varied keeping a constant concentration of $\mathrm{KMnO}_{4}$, while in the second set, the concentration of AMT was kept constant and the $\mathrm{KMnO}_{4}$ concentration was varied. $\mathrm{Log}$ absorbance versus $\log [\mathrm{AMT}]$ or $\left[\mathrm{KMnO}_{4}\right]$ was plotted to evaluate the slopes of the respective lines. The slope was found to be unity in each case thus indicating the molar combining ratio of 1:1 between Amitriptyline and potassium permanganate.

3.3. Formation constants

The formation constants for methods $\mathrm{A}, \mathrm{B}$ and $\mathrm{C}$ was estimated from Job's plot by following method described by Likussa and Boltz ${ }^{26}$, and Momoki et al ${ }^{27}$. The method involves drawing the tangents at the origin of Job's plot from both side and the absorbance at intersection point is taken for $100 \%$ complexation. The absorbance at peak height of Job's plot is taken for (100 - $x) \%$ where $x$ is the $\%$ degree of dissociation of the complex. The instability constant, $\mathrm{K}^{\prime}=\mathrm{Cx} /(100-\mathrm{x})$ is calculated, where $\mathrm{C}$ is concentration of drug used for Job's method. The reciprocal of $\mathrm{K}$ ' is the required stability constant $\mathrm{K}$.

3.4. Formation constant for method $E$

Formation constant $(\mathrm{K})$ has been evaluated by using Benesi-Hildebrand equation ${ }^{28}$

$$
\left[\mathrm{A}_{0}\right] / \mathrm{d}=\mathrm{I} / \mathrm{K}\left[\mathrm{D}_{0}\right] \varepsilon+1 / \varepsilon
$$

Where $\mathrm{d}$ is absorbance, $\varepsilon$ is molar absorptivity, $\mathrm{A}_{0}$ and $\mathrm{D}_{0}$ are initial concentrations of acceptor $\left[\mathrm{I}_{2}\right]$ and donor $[\mathrm{drug}]$ respectively. A plot of $\left[\mathrm{A}_{0}\right] / \mathrm{d}$ Vs $1 /\left[D_{0}\right]$ yields a straight line whose slope and intercept gives the value of $K$.
3.5. Optimization of the factors affecting the absorbance.

The factors effecting the absorbance of ion pair complexes like $p \mathrm{H}$ and volume of the dye, in methods $\mathrm{A}, \mathrm{B}$ and $\mathrm{C}$ have been optimized. $1.8 \mathrm{~mL}$ of BTB and buffer of $p H 2.8,1.6 \mathrm{~mL}$ of BPB and buffer of $p \mathrm{H} 2.5$ and $1.7 \mathrm{~mL}$ of BCP and buffer of $p \mathrm{H} 2.5$ are found to be optimal for methods A, B and C respectively. However $5 \mathrm{~mL}$ of each dye is used, at optimal $p \mathrm{H}$, in the study to ensure complete extraction of the drug. Similarly the $1 \mathrm{~mL}$ of iodine for method $\mathrm{D}$ and $1 \mathrm{~mL}$ of $\mathrm{KMnO}_{4}, 1 \mathrm{~mL}$ of $0.45 \mathrm{NaOH}$ for method $\mathrm{E}$ are found to be optimal and hence are used in the study.

3.6. Validation of the proposed methods

The proposed method have been validated in terms of guidelines proposed by ICH ${ }^{29}$ viz., selectivity, specificity, accuracy, precision, limits of calibration curve, LOD, LOQ, robustness, ruggedness and regression equation. The student $\mathrm{t}$-test and variance $\mathrm{F}$-test have been performed in comparison with a reference method. To test the reproducibility of the proposed methods, five replicate determinations of $15.0 \mu \mathrm{g} \mathrm{mL}$ of AMT were made. The coefficient of variation was found to be less than $1.2 \%$ for all the procedures.

The proposed methods have been successfully applied to the determination of AMT in pharmaceutical preparations. The results obtained and shown in Table II were compared to those obtained by a reference method ${ }^{4}$ by means of $t$-test at $95 \%$ confidence level. In all cases, the average results obtained by proposed methods and reference method were statistically identical, as the difference between the average values had no significance at $95 \%$ confidence level.

The proposed methods are simple, sensitive and reproducible and can be used for routine analysis of AMT in pure form and in formulation

\section{CONCLUSIONS}

The proposed spectrophotometric methods present selective and simple, specific and inexpensive analytical procedures for determination of AMT, in pure or in tablet dosage forms without interference from common excipients. Moreover, the developed methods are time saving and do not require elaborate treatments associated with chromatographic methods. These attributes, make them suitable for routine analysis in quality control laboratories.

\section{ACKNOWLEDGEMENTS}

Authors are thankful to the Head, Department of Chemistry and Principal Nizam College, Head Department of Chemistry, Jawaharlal Nehru Technological University Hyderabad, for providing laboratory facilities for this work.

\section{REFERENCES}

1. Goodman and Gilmans, The Pharmaceutical Basis of Therapeutics, 12th edition, 2010.

2. Kirk- othmer, Encyclopedia of Chemical Technology, John Wiley \& sons, $27^{\text {th }}$ volume, 2004.

3. W.C.Bowman and M.L.Rand, Textbook of Pharmacology, Blackwell Science publication, 1992

4. Pankaj Soni, Santosh K.Sar, Rajmani Patel, JASMI, 2,103, (2012)

5. A.A Omran, A.Y.El-Sayed, A.M.Shehata, M.Ahmed, M.A.El-Erian, $J$. Applied. Sci. Res. 3, 1730, (2007).

6. M.G. Gehad, A.F. Nour El-Dien, Faten, M.A.Nehad, Spectrochimica Acta. 68, 1244, (2007)

7. Seja Patel, N.J. Patel, Indian J.PharmSci.71, 472, (2009)

8. M.G. Gehad, A.F. Nour El-Dien, S.M. Khalil, M.A.Nehad, Spectrochimica Acta. 65, 1221,(2006).

9. J. O. Onah, Global. J. Pure. App. Sci. 11, 237, (2005).

10. J.Karpinska, J. Szostak, Spectrochimica Acta.61, 975, (2005)

11. A. Tehssen, A. A Kazi, I. H. Mohamed, A. Tal, Anal. Letters. 33, 2477, (2000).

12. F. A. Mohamed, H. A. Mohamed, S. A. Hussein, S. A. Ahmed, J. Pharm. Biomed. Anal. 39,139, (2005),

13. R.M. El-Nashar, N.T. Ghani Abdel, A.A. Bioumy, Microchemical J. 78, 107, (2004).

14. E.M. Elnemma, F.M. ElZawwy, S. M. Hassan, Saad, Microchimica Acta 110, 79, (1993)

15. T.Ghani Nour, A. El. Nashar, R. M. Bioumy, A. Abeer, FABAD. J. Pharm. Sci. , 29, 195, (2004).

16. C. Jessica, R. Alberto, A. Emillio, J. Elena, J. Incl. phenom Macrocycl che. (2007) 
17 W. Lu, S. A. Shamsi, T.D. McCarley, I.M. Warner, Electrophoresis, 19, 2193, (1998).

18. K.L.Johnson-Davis, J.M.Juenke, R.Davis, G.A. McMillin, Methods.Mol. Biol. 902, 175, (2012)

19. Susheela Rani, Ashwini Kumar, Ashok Kumar Malik, Baldev Singh, MS, Chromatographia.74, 235, (2011)

20. G.M. Greenway, Sarah J.L.Dolman, Analyst, 124,759, (1999)

21. J.Trocewicz, J. Chromatogr. B, 801, 213, (2004)

22.S.D Lamani ,S.T. Nandibewoor, J. Thermodyn Catal. 2,110, (2011)

23. J.C.Miller, J.N.Miller, Statistics and chemometrics for Analytical Chemistry, Harlow, England, 2005.
24. P. Job, Anal. Chim Acta. 9, 113, (1928).

25. J. Rose Advanced Physicochemical Experiments, Pitman, London, UK, 1964.

26. W. Likussar D.F. Boltz, Anal. Chem. 43, 1265, (1971).

27. K. Momoki, J. Sekino, H. Sato, N. Yamaguchi, Anal. Chem. 41, $1286,(1969)$

28. H. A. Benesi, J. R Hildebrand, J. Am. Chem. Soc. 71, 2703, (1949).

29. International Conference on Harmonization (ICH) of Technical Requirement for the Registration of Pharmaceuticals for Human use, Validation of analytical procedures: definitions and Terminology Genera (1996). 